TEKNIK, 41 (1), 2020, 40-47

\title{
Pemodelan Pupuk Rilis Lambat Dengan Fly Ash sebagai Matriks Inert yang Dilapisi oleh Ethylcellulose
}

\author{
Kemal Maulana, Mohamad Djaeni * \\ Departemen Teknik Kimia Fakultas Teknik, Universitas Diponegoro, \\ Jl. Prof. Soedarto, SH, Kampus UNDIP Tembalang, Semarang, Indonesia 50275
}

\begin{abstract}
Abstrak
Pupuk lambat rilis memiliki peranan yang penting dalam mencegah hilangnya nutrisi tanaman serta meningkatkan efisiensi penyerapan. Penelitian ini bertujuan untuk memperoleh nilai koefisien difusivitas ethylcellulose melalui perbandingan antara laju rilis pellet urea eksperimen dengan laju rilis pellet urea simulasi. Penelitian ini menggunakan metode elemen hingga 2D dengan software Comsol Multiphysics. Melalui perbandingan menggunakan hasil eksperimen dengan simulasi diperoleh hasil difusivitas pada lapisan ethylcellulose bervariasi antara $6 \times 10^{-3}-9 \times 10^{-3} \mathrm{~cm}^{2} /$ hari dengan Root Mean Square Error (RSME) sebagai indikator error perhitungan memiliki nilai antara 0.675 - 1.791. Hasil tersebut menunjukkan bahwa model cukup baik untuk menggambarkan karakteristik difusi urea dari matriks ke air.
\end{abstract}

Keywords: fly ash; pupuk lambat rilis; ethylcellulose; difusivitas; comsol multiphysics

\begin{abstract}
Slow release fertilizer have important role in preventing losses of plant nutrients and increasing absorption efficiency. This study aims to obtain the value of ethylcellulose diffusivity coefficient through a comparison between the experimental urea pellet release rate and the simulated urea pellet release rate. This research uses 2D finite element method with the Comsol Multiphysics. Through comparison using the results of experiments with simulations, the diffusivity results obtained in the ethylcellulose layer vary between 6 × 10-3 - $9 \times$ 10-3 cm2 / day with Root Mean Square Error (RSME) as an indicator of calculation error has a value between $0.675-1.791$. This result indicated that the model is good enough to describe the diffusion of urea from matrix to the water.
\end{abstract}

Keywords: fly ash; slow release fertilizer; ethylcellulose; difusivity; comsol multiphysics

\section{Pendahuluan}

Pupuk lambat rilis (CRF) dimaksudkan untuk mengendalikan pelepasan nutrisi dari waktu ke waktu dan bukan untuk segera larut di tanah yang lembab setelah pupuk diaplikasikan. Konsentrasi hara dijaga agar sesuai sehingga membantu mencegah hilangnya unsur hara dan meningkatkan efisiensi pemanfaatan hara oleh tanaman (Trenkel, 1997).

Peningkatan efisiensi penggunaan pupuk $\mathrm{N}$ mempunyai peranan yang penting untuk mewujudkan pertanian yang berkelanjutan. Peningkatan efisiensi penggunaan pupuk $\mathrm{N}$ untuk meningkatkan hasil produksi pertanian dengan penggunaan pupuk $\mathrm{N}$ yang efisien. Peningkatan efisiensi penggunaan pupuk $\mathrm{N}$ bisa

\footnotetext{
${ }^{*}$ Penulis Korespondensi.

E-mail: moh.djaeni@live.undip.ac.id
}

dilakukan dengan pemberian sumber nutrisi atau unsur hara untuk tanaman yang berimbang dan dosis yang sesuai dengan rekomendasi, waktu pemberian pupuk yang tepat, penggunaan pupuk slow realease, penggunaan penghambat nitrifikasi (nitrification inhibitor) dan aplikasi pemupukan secara berimbang dengan menggunakan pupuk kimia, pupuk hijau, dan pupuk kandang (Prasad, 2009). Selain itu, real time nitrogen management merupakan salah satu teknologi untuk mengatur penggunaan pupuk $\mathrm{N}$ dan jumlah unsur hara yang dihasilkan oleh pupuk yang disesuaikan dengan kebutuhan tanaman (slow realease/controlled realease fertilizer) (Xiang \& Ji-yun, 2008).

Efisiensi pupuk yang diterima tanaman bila diaplikasikan dalam bentuk konvensional hanya sekitar 30$50 \%$. CRF meminimalkan kerugian pada pupuk yang mungkin diakibatkan adanya penguapan atau pencucian, sehingga mencegah kerusakan pada benih. CRF juga 


\section{TEKNIK, 41 (1), 2020, 41}

memberikan perlindungan yang baik terhadap ekosistem jika bahan pelapis pupuk memiliki sifat biodegradable (AlZahrani, 1999). Urea terpilih sebagai bahan yang akan dilapisi karena kandungan nitrogennya yang tinggi, rendah biaya, serta alasan komersial (Kent, 2007).

Shaviv $d k k$. (2003) melakukan studi tentang penerapan teknologi pupuk lambat rilis dimana hara yang dilepaskan oleh pupuk biasanya dikendalikan oleh difusi melalui lapisan pelapis Salah satu faktor utama yang mengendalikan pelepasan adalah pecahnya lapisan membran yang ditemukan pada pupuk urea yang dilapisi oleh belerang. Trinh $d k k$. (2013) mempelajari difusifitas pelepasan urea slow release dengan pelapis material tertentu.

Gambash dkk. (1990) menggunakan model semi empiris pada studi mereka, dan efek geometri dan ukuran diabaikan. Selain asumsi ini, periode lag, dimana tidak ada pelepasan diamati, tidak disertakan. (Lu \& Lee, 1992) menerapkan hukum Fick dalam bentuk bola pada urea yang dilapisi oleh lateks. (Al-Zahrani, 1999) memodelkan pelepasan dalam kondisi unsteady dari partikel membran polimer dan diasumsikan kondisi tercampur baik dalam partikel bola. Sebagian besar upaya pemodelan ini didasarkan pada asumsi bahwa pelepasan nutrisi dari pupuk lambat rilis dikendalikan oleh difusi zat terlarut sederhana. Berdasarkan percobaan terbukti bahwa pelepasan dari granul tunggal pupuk lambat rilis yang dilapisi polimer terdiri dari tiga tahap: tahap awal dimana tidak ada pelepasan yang diamati (periode lag), sebuah tahap konstan rilis, dan akhirnya tahap peluruhan akhir (Shaviv $d k k$., 2003). Lu $d k k$. (2007) mengajukan sebuah model matematika untuk urea berlapis polimer yang juga memperhitungkan pengaruh populasi dari butiran Model ini didasarkan pada persamaan keseimbangan massa dari hukum Fick. Namun, tahap pertama proses pelepasan diabaikan.

Sebagian besar penelitian di bidang ini hanya berkonsentrasi pada difusi urea sederhana melalui lapisan pelapis tanpa mempertimbangkan difusi melalui multilayer (lapisan dan lingkungan). Untuk memiliki wawasan yang lebih dalam maka penelitian ini dilakukan dengan menyelidiki pelepasan urea pada fase rilis konstan dan fase peluruhan akhir adapun material yang digunakan merupakan pellet urea yang terbuat dari urea, fly ash dan clay lalu dilapisi dengan ethylcellulose. Fly ash dengan butiran yang berbentuk bundar atau bola-bola beraturan biasanya sangat aktif, sehingga mudah mengeras apabila dicampur dengan kapur atau air. Dengan demikian fly ash memiliki sifat sebagai pengikat jika dicampur dengan air (Kamalakar, 2011).

\section{Bahan dan Metode}

Gambar 1. mengilustrasikan model peluruhan pellet urea pada 2D koordinat-yz. Pada model ini, pellet urea yang telah dilapisi dikelilingi oleh air. Pellet urea terdiri dari dua bagian: matriks urea dan lapisan ethylcellulose di luar matriks urea. Diasumsikan bahwa pada saat terjadi peluruhan lapisan ethylcellulose di bagian luar dalam kondisi jenuh dengan air.

Air pada permukaan matriks urea akan mulai melarutkan matriks urea tersebut. Larutan urea ini dijaga pada kondisi jenuh selama matriks urea masih berada di intinya. Urea mulai terlepas melalui lapisan pelapis melalui proses difusi. Berdasarkan persamaan transport massa dalam medium berpori untuk difusi urea, $D_{e}$, melalui lapisan pelapis bisa ditulis seperti pada Pers. 1 (Lu dkk., 2007).

$$
D_{e}\left[\frac{\partial^{2} C}{\partial r^{2}}+\frac{2}{r} \frac{\partial C}{\partial r}\right]=\varepsilon \frac{\partial C}{\partial t}
$$

Karena pellet urea tidak bergerak, diasumsikan bahwa fluks urea dari permukaan pelapis ke cairan dikendalikan oleh difusi urea dalam cairan. Oleh karena itu, dihitung berdasarkan persamaan transport massa urea dalam air sebagai berikut. 2 dan Pers. 3:

$$
\begin{aligned}
& D_{\text {urea }} \frac{\partial^{2} C}{\partial r^{2}}+\frac{2 D_{\text {urea }}}{r} \frac{\partial C}{\partial r}=\frac{\partial C}{\partial t} \\
& D_{\text {urea }}=\left(1.380-0.0782 C+0.00464 C^{2}\right) 10^{-5} \mathrm{~cm}^{2} / \mathrm{s}
\end{aligned}
$$

Dalam zona air, difusi urea dalam cairan, $D_{\text {urea }}$, dinyatakan dalam $\mathrm{cm}^{2} / \mathrm{s}$. Nilai $D_{\text {urea }}$ bervariasi sesuai dengan konsentrasi, $C$, seperti yang dijelaskan oleh persamaan. Pupuk rilis lambat yang digunakan berupa pellet urea yang terlapisi oleh ethylcellulose yang dimasukkan dalam medium air seperti ditunjukkan pada Gambar 1. Diasumsikan bahwa pellet urea simetris di seluruhnya sumbu horizontal sehingga modelnya dapat digambarkan sebagai setengah lingkaran pellet urea. Model 2D dari urea pada medium air ditunjukkan pada Gambar 2. Saat pupuk kontak dengan air, dibasahi untuk periode yang disebut jeda waktu $\left(\mathrm{t}_{0}\right)$. Pada saat lapisan ethylcellulose jenuh dengan air, maka pelepasan nitrogen dalam bentuk urea dimulai.

Air dalam inti akan melarutkan urea dalam pellet dan nitrogen berdifusi melalui pelapis ke lingkungan. Dalam model ini, transportasi nitrogen melalui lapisan ethylcelulose bisa digambarkan dengan transportasi pada media berpori. Transportasi transien adalah diwakili oleh persamaan 1 dan 2.

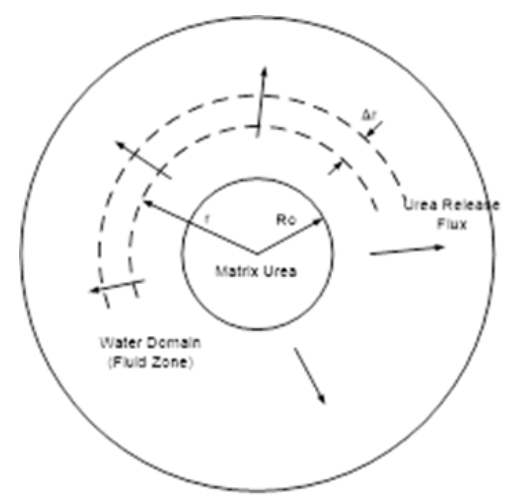

Gambar 1. Permodelan 2D pada urea pellet (Meena $d k k ., 2019)$ 


\section{TEKNIK, 41 (1), 2020, 42}

Water Domain

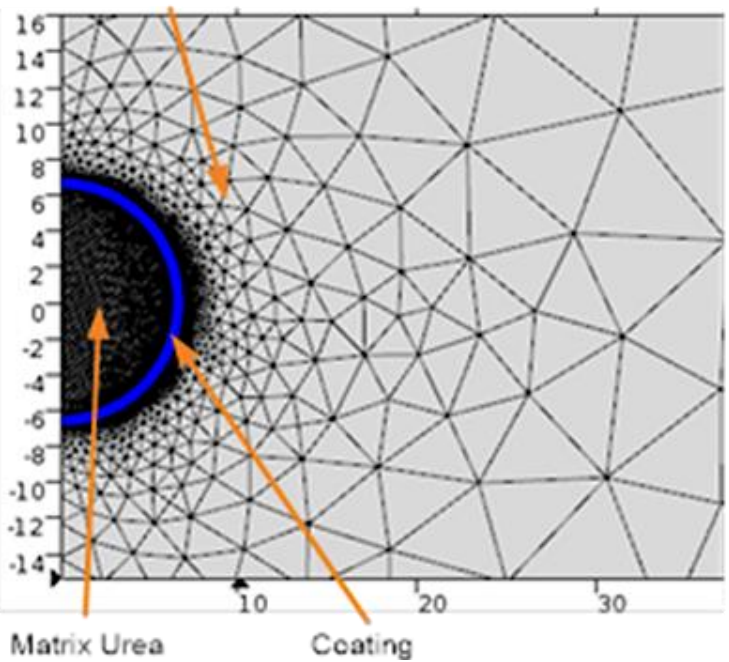

Gambar 2. Meshing $2 D$ pada urea pellet (Meena $d k k$., 2019)

Metode elemen hingga (FEM) dan geometri 2D diusulkan untuk memecahkan model pelepasan urea. Model ini dikhususkan untuk pupuk rilis lambat yang dilapisi dengan bahan pelapis seperti ethylcellulose. Geometri dan meshing untuk pellet urea ditunjukkan pada Gambar 1b. Diameter zona fluida yaitu jarak dari pusat granul urea sampai batas air sebesar 22 kali jari-jari inti $\left(\mathrm{R}_{0}\right)^{[11]}$. Nilai awal dan kondisi batas ditentukan untuk model. Saat $t_{0}$ (diperoleh dari percobaan), larutan urea pada permukaan inti urea jenuh, dan konsentrasi nol pada lapisan luar bidang cairan. Dalam simulasi ini, waktu pelepasan urea bergantung pada jumlah urea (ukuran dan bentuk) dan sifat material pelapis (ketebalan, difusivitas, porositas). Perhitungan dinyatakan usai rilis urea pada matriks larut seluruhnya. Pada saat itu, seluruh urea bersifat cair dan setara dengan konsentrasi urea jenuh $\left(m_{\text {core }}=m_{\text {sat }}\right)$.

Model ini didasarkan pada asumsi : (1) Pelepasan nitrogen (dalam bentuk pellet) adalah dengan cara difusi, dan tidak ada aliran air dalam lingkungan (kondisi stagnan); (2) Suhu tetap konstan selama waktu rilis; (3) Tidak ada reaksi yang berakibat hilangnya nitrogen. Pada aplikasi dalam tanah urea berubah menjadi amonium dengan adanya urease. Karena itu transformasi urea oleh urease diminimalkan.

\subsection{Material}

Bahan yang digunakan sebagai pellet terdiri dari : urea (46.4\% nitrogen), fly ash dan clay yang berasal dari PT. Pupuk Sriwidjaja Palembang. Ethanol yang digunakan merupakan produk Merck $\left(99,9 \%, \mathrm{M}_{\mathrm{w}}=46,07\right.$ $\mathrm{gr} / \mathrm{mol})$. Polimer etilselulosa dengan merek dagang komersial ETHOCEL (The Dow Chemical Company,
Michigan, USA) digunakan sebagai bahan pelapis dalam pembuatan pupuk rilis lambat. Ethylcellulose adalah turunan selulosa multifungsi dan tidak larut dalam air. Polimer ini tidak berwarna, tidak berbau dan tidak berasa serta banyak diaplikasikan untuk mengendalikan pelepasan nutrisi dari pupuk atau bahan aktif dari obatobatan. Struktur etilcelulosa disajikan pada Gambar 1.

\subsection{Persiapan material}

\subsubsection{Pembuatan pellet urea}

Komposisi pellet urea terdiri dari : urea granule, fly ash dan clay. Urea granule terlebih dahulu dihaluskan lalu dicampur dengan fly ash dan clay. Setelah tercampur lalu disemprot larutan pati $10 \%$ sebagai bahan perekat di dalam matriks. Selanjutnya campuran tersebut dimasukkan dalam alat pembuat tablet sehingga diperoleh pellet urea dalam bentuk silinder. Adapun parameter dan variabel yang digunakan dalam penelitian ini dapat dilihat pada Tabel 1.

Tabel 1. Parameter dan variabel yang digunakan

\begin{tabular}{lll}
\hline Parameter & Simbol & Nilai Parameter \\
\hline Ketebalan coating & 1 & $0.71 \mathrm{~mm}$ \\
Jari-jari pellet & $\mathrm{R}_{\mathrm{o}}$ & $13 \mathrm{~mm}$ \\
Tinggi pellet & $\mathrm{h}$ & $24 \pm 0.04 \mathrm{~mm}$ \\
Massa jenis Urea & $\rho_{\text {urea }}$ & $1320 \mathrm{~kg} / \mathrm{m}^{3}$ \\
Massa jenis Fly ash & $\rho_{\text {fly ash }}$ & $800 \mathrm{~kg} / \mathrm{m}^{3}$ \\
Massa jenis Clay & $\rho_{\text {clay }}$ & $2650 \mathrm{~kg} / \mathrm{m}^{3}$ \\
\hline
\end{tabular}

\subsubsection{Pembuatan larutan ethylcelluose}

Mula-mula dilakukan penimbangan terhadap pellet urea yang telah dibuat. Lalu pellet urea tersebut dilapisi dengan ethylcellulose dengan metode perendaman. Untuk hal ini disiapkan larutan 10\% ethylcellulose dalam etanol. Pellet urea lalu dicelupkan ke dalam larutan (dengan kontak waktu 2-3 detik) pada suhu konstan $25^{\circ} \mathrm{C}$, kemudian dikeringkan pada suhu $80^{\circ} \mathrm{C}$ untuk menguapkan residu etanol.

\subsubsection{Rilis konsentrasi urea dalam larutan air distilasi \\ Pengukuran konsentrasi urea dilakukan dengan} metode in vitro. Pellet urea yang akan dilakukan pengujian dicelupkan dalam $1000 \mathrm{ml}$ aquadest suhu $24^{\circ} \mathrm{C}$. Pada selang waktu tertentu dilakukan pengambilan sampel untuk menentukan konsentrasi urea yang ada dalam larutan air tersebut. Sejumlah $25 \mathrm{ml}$ larutan sampel diambil lalu ditambahkan $20 \mathrm{ml}$ reagen $\mathrm{p}$ dietilaminbenzaldehide. Aduk dengan sempurna lalu biarkan hingga 5 menit. Konsentrasi urea diketahui melalui kurva kalibrasi pada spektrometer UV-VIS Merk Shimadzu Type UV 1800 dengan panjang gelombang yang digunakan sebesar $430 \mathrm{~nm}$. 


\section{TEKNIK, 41 (1), 2020, 43}

\subsection{Model performa}

Kinerja model dinilai dengan menggunakan akar kuadrat kesalahan (RMSE) didefinisikan sebagai berikut dalam persamaan 4 (Xiang and Ji-Yun, 2008).

$$
R M S E=\sqrt{\frac{\sum\left(y_{p}-y_{m}\right)^{2}}{n}}
$$

$y_{p}$ adalah nilai terukur dari pelepasan nutrisi, $y_{m}$ adalah nilai prediksi pelepasan nutrisi, dan $\mathrm{n}$ adalah banyak data penelitian.

Terdapat beberapa bahan yang tersedia di alam yang meluruh perlahan dan kandungan nutrisi dalam materi tersebut mungkin tersedia untuk waktu yang lama. Fly ash adalah salah satu bahan yang dapat dianggap sebagai pupuk pelepasan terkontrol dan telah digunakan di lahan pertanian. Praktik dan manfaatnya telah direalisasikan sejak dahulu kala.

Fly ash dipilih sebagai matriks karena murah dan mudah tersedia bagi petani sehingga cocok untuk bahan matriks. Beberapa agen pengikat dapat digunakan untuk penelitian seperti semen, tar, plester paris, natrium silikat, kapur menonjol. Tapi clay telah dipilih untuk penelitian ini sebagai bahan pengikat (binder) terutama karena mudah diperoleh dan murah (Kamalakar, 2011).

\section{Hasil dan Pembahasan}

Untuk memperoleh data hasil yang paling bagus membutuhkan eksperimen, namun eksperimen membutuhkan banyak waktu dan biaya. Untuk memudahkan pemahaman terkait penelitian ini maka hasil penelitian dibagi menjadi 2 bagian. Pada bagian pertama nilai koefisien diffusivitas ethylcellulose dicari melalui perbandingan data eksperimen dengan hasil simulasi yang dilakukan lalu dihitung nilai $R S M E$ antara kedua data tersebut, semakin rendah nilai RSME mengindikasikan bahwa asumsi nilai koefisien diffusivitas yang digunakan dalam simulasi dapat diterima. Pada bagian kedua dibandingkan pengaruh fly ash maupun clay dengan variabel konsentrasi urea yang sama terhadap laju rilis urea ke lingkungan.

\subsection{Perbandingan hasil simulasi dengan percobaan}

Untuk membuat permodelan mula-mula ditentukan parameter yang akan digunakan. Tabel 1. berisi parameter yang dipakai dalam permodelan setelah itu disusun geometri yang akan menjadi lingkup simulasi lalu dilakukan meshing seperti yang terlihat pada Gambar 2. adapun ketebalan lapisan ethylcellulose diperoleh dari pengukuran menggunakan SEM, ketebalan lapisan rata-rata ethylcellulose pada pellet adalah $0,71 \mathrm{~mm}$. Hal ini dapat dilihat pada Gambar 3 (a) dimana dilakukan perbesaran x50 pada lapisan ethyl cellulose.
Pada Gambar 3 (b) dan 3 (c) dapat dilihat morfologi dari pelapis ethylcellulose secara jelas. Nampak lapisan yang dibentuk tidak seragam karena viskositas ethylcellulose yang tinggi sehingga pada beberapa bagian urea pellet memiliki ketebalan yang lebih dibanding bagian yang lainnya.

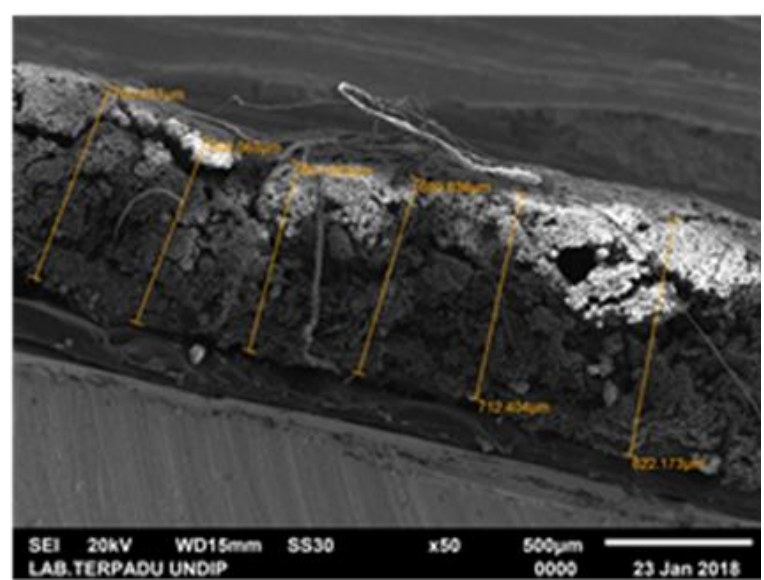

Gambar 3a. Hasil SEM pada pembesaran x50

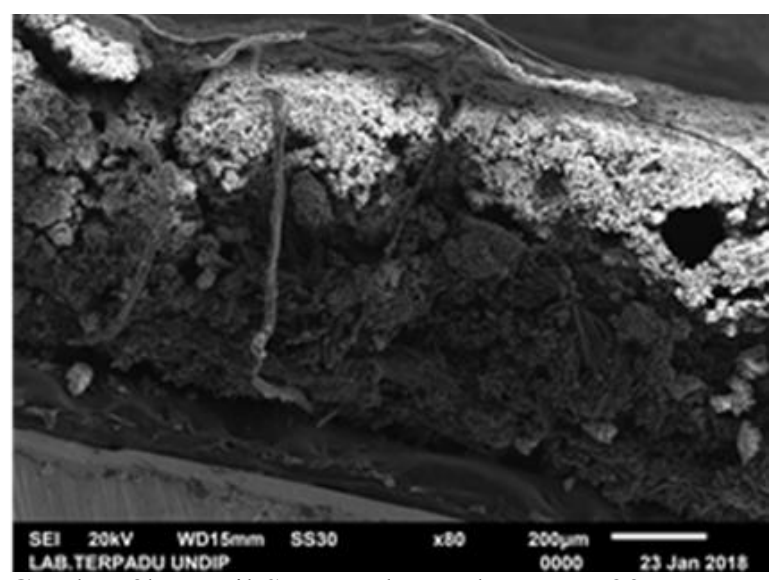

Gambar 3b. Hasil SEM pada pembesaran x80

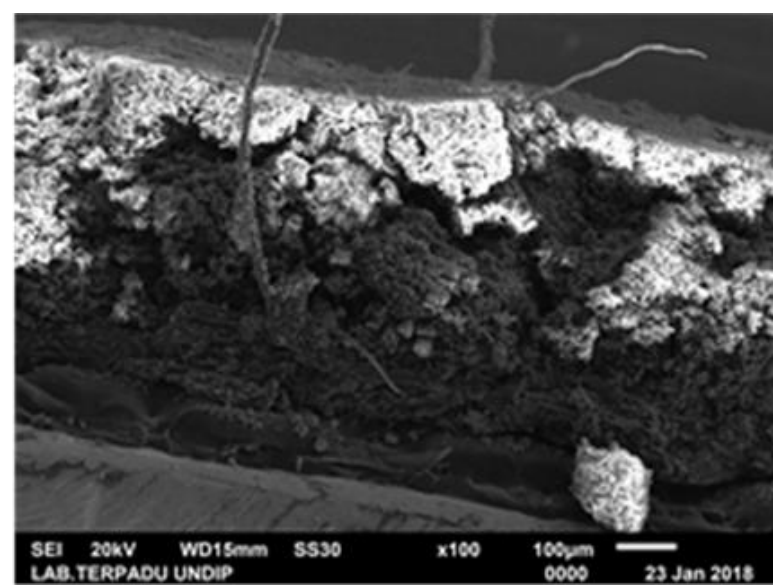

Gambar 3c. Hasil SEM pada pembesaran x100 


\section{TEKNIK, 41 (1), 2020, 44}

Kemudian dilakukan trial terhadap koefisien difusivitas ethylcellulose pada software COMSOL, Root Mean Square Error (RMSE) digunakan untuk menentukan perbedaan antara data hasil simulasi dengan data percobaan (Grewal, 2017). Pada Gambar 4 diperlihatkan perbandingan antara hasil simulasi dengan percobaan dengan nilai RSME sebesar 0.845, dimana hasil perbandingan ini dapat diterima untuk menjelaskan gambaran rilis nitrogen dalam sistem. Perbedaan yang terjadi pada hasil simulasi dengan percobaan terjadi akibat tidak seragamnya urea pellet yang dibuat dan kurang sempurnanya pelapis yang dibentuk. Pada Gambar 4 diperoleh grafik berupa kurva yang menjelaskan perubahan dari rilis konstan menjadi rilis akhir. Hal ini sesuai dengan literatur (Cussler, 2009; Lu \& Lee, 1992; Shaviv, 2003).

Perubahan massa urea dalam inti serta pada lapisan ditunjukkan sebagai fungsi waktu. Pada simulasi ditunjukkan pada Gambar 5 dan Gambar 6. Pada waktu t $=0$, inti dalam urea dilarutkan oleh air yang berada pada lapisan ethylcellulose. Konsentrasi pada inti urea masih berada pada tingkat jenuh.

Seperti pada Gambar 5, massa pelllet tetap konstan, sedangkan inti urea cepat berkurang pada awal rilis. Penundaan pelepasan urea bisa dijelaskan dengan melihat pada profil konsentrasi urea (Gambar 5). Urea tidak ada pada lapisan ethylcellulose pada waktu $\mathrm{t}=0$. Setelah urea terlarut, namun masih harus melewati lapisan sebelum terlepas pada lingkungan. Saat urea mencapai antarmuka antara lapisan dan lingkungan, pelepasan dimulai dan meningkat hingga mencapai konstan Selama tahap pelepasan konstan, jumlah urea masuk ke lapisan sama dengan jumlah urea dilepaskan ke lingkungan.

Hal ini juga ditunjukkan pada Gambar 5 bahwa tidak terjadi perubahan konsentrasi urea pada lapisan pelapis. Sebuah studi simulasi rilis urea pada fase akhir yang terlepas di dalam air ditunjukkan pada Gambar 6.

Pertama, tidak ada urea di zona air, dan karenanya Konsentrasi urea di zona air tidak berubah pada saat awal fase rilis akhir, tanda panah menggambarkan profil rilis urea ke dalam air. Terlihat konsentrasi urea pada lapisan ethylcelulose semakin berkurang seiring bertambahnya waktu. Konsentrasi di zona air terus meningkat selama pelepasan konstan karena akumulasi urea. Tahap pelepasan akan berakhir saat urea benarbenar larut. Pada saat ini, massa urea setara dengan konsentrasi urea jenuh.

Pada Tabel 2 kita dapat melihat nilai koefisien difusivitas yang diperoleh pada berbagai sampel dengan nilai RMSE sebagai perbedaan nilai antara hasil simulasi dengan hasil eksperimen yang telah dilakukan.

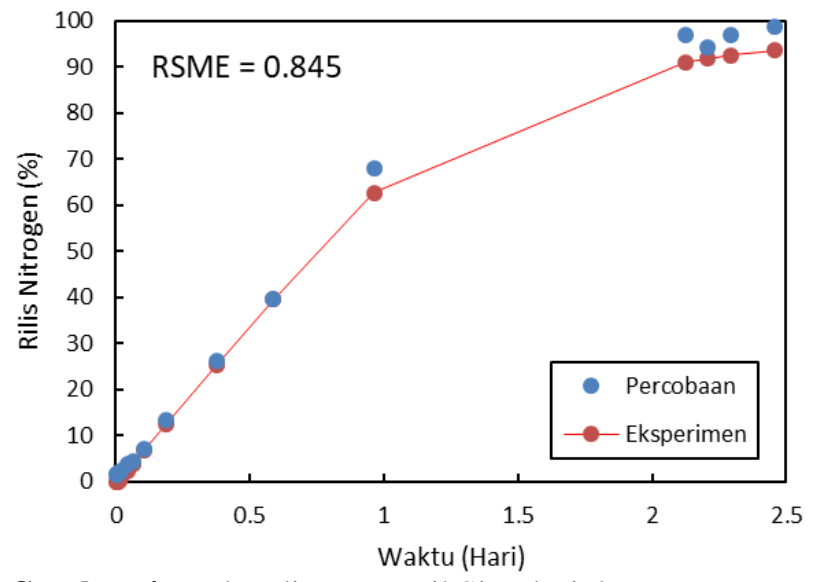

Gambar 4. Perbandingan Hasil Simulasi dengan

Percobaan

Tabel 2. Hasil data penelitian dan simulasi

\begin{tabular}{ccccc}
\hline No. & Notasi & $\begin{array}{c}\text { Urea }: \text { Fly } \\
\text { Ash }: \text { Clay } \\
(\%)\end{array}$ & $\begin{array}{c}\text { Koefisien } \\
\text { Difusivitas } \\
\left(\mathbf{c m}^{2} / \text { hari }\right)\end{array}$ & RMSE \\
\hline 1 & UP 1 & $50: 40: 10$ & $6 \times 10^{-3}$ & 1.399 \\
2 & UP 2 & $40: 40: 20$ & $9 \times 10^{-3}$ & 0.845 \\
3 & UP 3 & $40: 20: 40$ & $8 \times 10^{-3}$ & 1.071 \\
4 & UP 4 & $40: 30: 30$ & $6 \times 10^{-3}$ & 0.675 \\
5 & UP 5 & $50: 20: 30$ & $8 \times 10^{-3}$ & 1.791 \\
\hline
\end{tabular}

\subsection{Pengaruh Fly Ash dan Clay terhadap rilis Nitrogen}

Pada Gambar 7 (a) dan 7 (b) percobaan dilakukan dengan menggunakan urea pellet yang memiliki kandungan fly ash yang sama. Pelepasan nutrisi karena interaksi pengikat matriks inert dengan binder (clay) menghasilkan tingkat pelepasan yang lebih rendah. Pada Gambar 7 (a) dan Gambar 7 (b) dilakukan perbandingan pada urea pellet dengan kandungan fly ash sebesar $40 \%$ (UP 1 VS UP 2) tingkat pelepasan rilis nitrogen lebih rendah dicapai oleh urea pellet UP 1 (clay 10\%). Hal yang sama juga terjadi pada UP 3 VS UP 5 dengan kandungan fly ash sebesar 20\% tingkat pelepasan rilis nitrogen kedua sampel hampir serupa. Jika dibandingkan kedua gambar tersebut terlihat bahwa dengan semakin tingginya komposisi clay dalam urea pellet semakin rendah pula kecepatan rilis yang terjadi. Clay sebagai binder merupakan komponen penting yang menentukan cepat atau lambatnya rilis unsur hara dalam matriks rilis lambat. Fungsi binder mutlak diperlukan namun komposisi dalam matriks harus diperhatikan sehingga dapat diperoleh nilai rilis lambat yang optimum (Kamalakar, 2011; Bita dkk., 2015). 
TEKNIK, 41 (1), 2020, 45

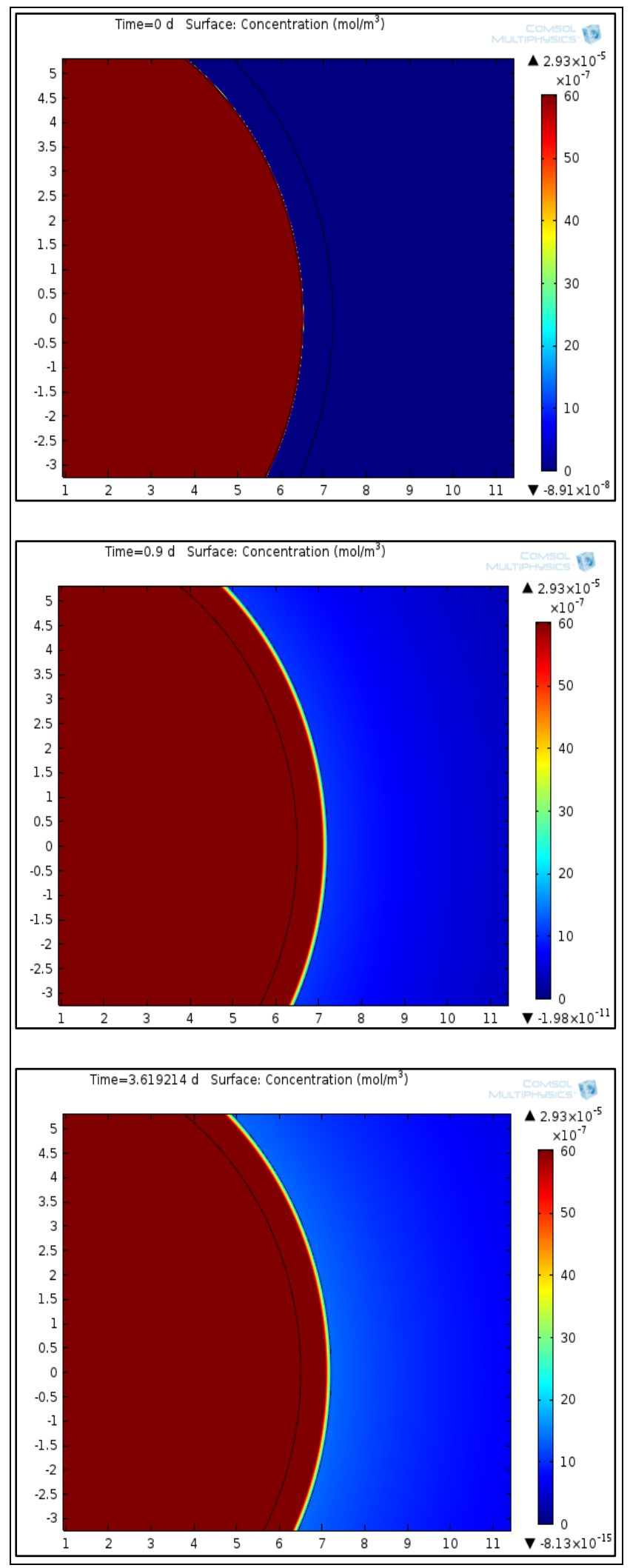

Gambar 5 . Profil konsentrasi urea fase rilis konstan.
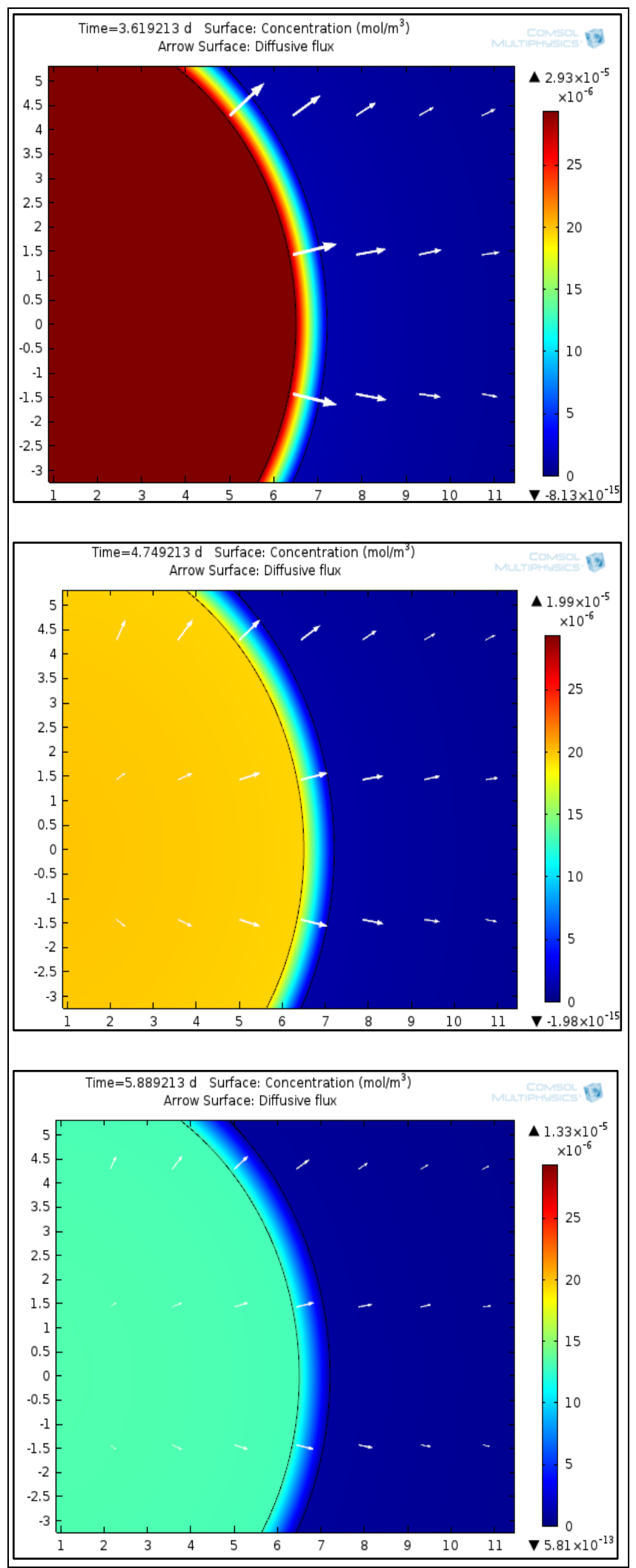

Gambar 6. Profil konsentrasi urea pada fase rilis akhir. 


\section{TEKNIK, 41 (1), 2020, 46}

Pada Gambar 8, ditunjukkan perbedaan antara sampel UP 4 dengan UP 5 dengan kandungan clay yang serupa yakni sebesar $30 \%$ terlihat bahwa sampel UP 4 dengan kandungan fly ash sebesar $30 \%$ memiliki nilai rilis nitrogen yang lebih rendah. Berarti untuk sementara bahwa adanya fly ash menurunkan kemampuan atau kecepatan difusi urea dari matrix. Fly ash dan clay memiliki fungsi yang serupa dengan penyusunan matriks rilis lambat yaitu sama-sama membentuk ikatan yang menghambat laju rilis nitrogen ke lingkungan. Namun kuantitas fly ash yang dapat digunakan dalam matriks harus juga diperhatikan karena nilai rilis lambat tergantung dari beberapa faktor, antara lain : rasio matriks, jenis binder yang digunakan serta unsur hara yang digunakan dalam penyusunan matriks rilis lambat (Sitanggang, 2017).

\section{UP 1 VS UP 2}

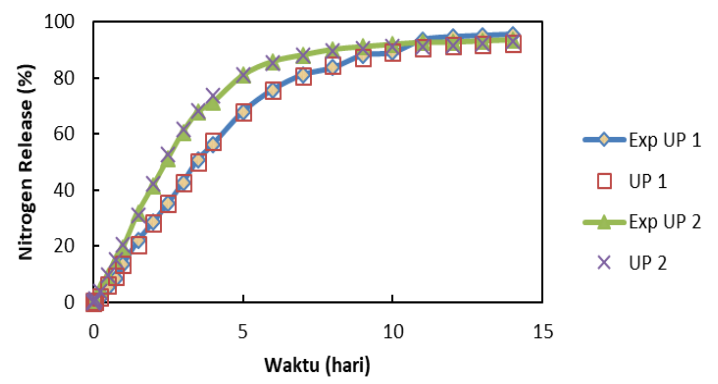

Gambar 7 (a). Perbandingan rilis nitrogen pada kandungan fly ash yang sama.

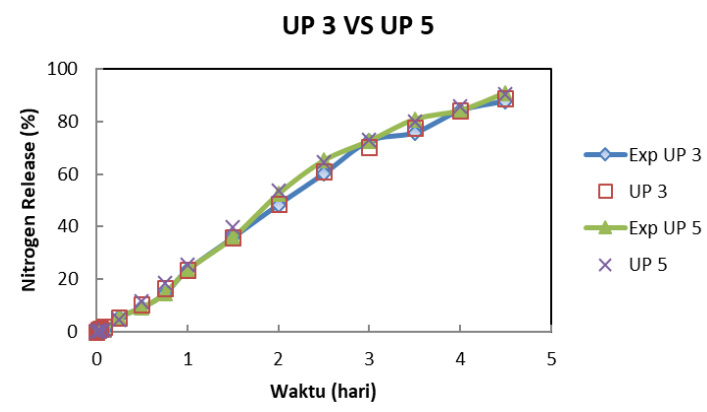

Gambar 7 (b). Perbandingan rilis nitrogen pada kandungan fly ash yang sama.

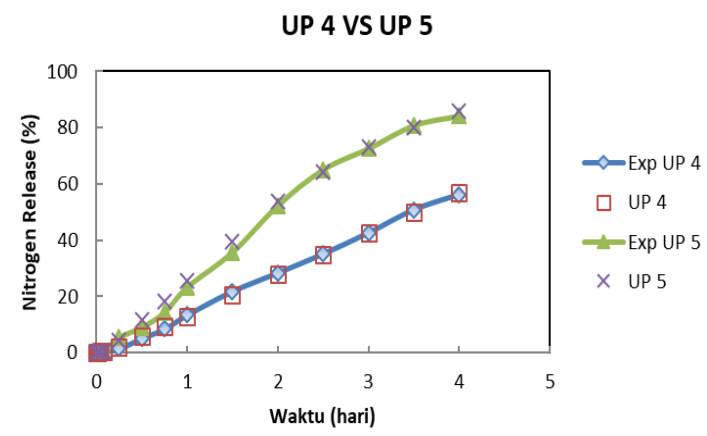

Gambar 8. Perbandingan rilis nitrogen pada kandungan clay yang sama.

\section{Kesimpulan}

Penelitian dilakukan dengan membentuk permodelan rilis nitrogen dalam bentuk 2D lalu membandingkan dengan data rilis nitrogen yang diperoleh melalui percobaan. Nilai koefisien difusifitas yang diperoleh berkisar antara $6 \times 10^{-3}-9$ x $10^{-3} \mathrm{~cm}^{2} /$ hari dengan Root Mean Square Error (RSME) sebagai indikator eror perhitungan memiliki nilai antara $0.675-1.791$.

Melalui perbandingan antara sampel dapat disimpulkan bahwa rilis nitrogen ke lingkungan akan semakin cepat jika komposisi binder pada pellet urea semakin besar. Fungsi binder sebagai penyusun matriks rilis lambat mutlak diperlukan namun komposisinya harus diperhatikan sehingga rilis nitrogen yang diperoleh dapat mencapai nilai optimum. Sementara itu rilis nitrogen ke lingkungan akan semakin rendah jika komposisi fly ash pada pellet urea semakin tinggi.

\section{Daftar Pustaka}

Al-Zahrani, S. M. (1999) Controlled-release of fertilizers: modelling and simulation. Int. J. Eng. Sci., 37, 1299-307.

Bita, R., Shahram, M. S., \& Suraya, A. R. (2015) Enhancement of nitrogen release properties of urea-kaolinite fertilizer with chitosan binder. Chemical Speciation \& Bioavailability., 27, 4451

Cussler E. L. (2009), Diffusion: Mass Transfer in Fluid Systems, Ed.3, Cambridge: Cambridge University Press.

Gambash, S., Kochba, M., \& Avnimelech, Y. (1990) Studies on Slow-Release Fertilizers: II. A Method for Evaluation of Nutrient Release Rate From Slow-Releasing Fertilizers. Soil Sci.,150, $446-450$.

Grewal, B. S. (2017), Higher Engineering Mathematics, $43^{\text {rd }}$ ed., New Delhi: Khanna Publisher.

Kamalakar, D. (2011) Zinc Sulfate Controlled Release Fertilizer with Fly Ash as Inert Matrix. Indian Streams Research Journal, 1(5).

Kent, J. A. (2007) Kent and Riegel's Handbook of Industrial Chemistry and Biotechnology. Verlag: Springer.

Lu, S. M., Chang, S.-L., Ku, W.-Y., Chang, H.-C., Wang, J.-Y. \& Lee, D.-J. (2007) Urea release rate from a scoop of coated pure urea beads: Unified extreme analysis. J. Chin. Inst. Chem. Eng., 38, 295-302.

Lu, S. M. \& Lee, S. F. (1992) Slow release of urea through latex film. J. Controlled Release, 18, $171-80$. 


\section{TEKNIK, 41 (1), 2020, 47}

Meena, S.O., Vashishtha, M., and Meena, A. (2019) Modelling and Simulation of Nutrient Release from Neem (Azadirachta Indica) Oil Coated Urea. J. Adv. Agric. Technol., 6, 32-37.

Prasad, R. (2009). Efficient fertilizer use: The key to food security and better environment. Journal of Tropical Agriculture, 47, 1-17.

Shaviv, A., Raban, S., \& Zaidel, E. (2003) Modeling Controlled Nutrient Release from Polymer Coated Fertilizers: Diffusion Release from Single Granules. Env. Sci Technol, 37, 2251-6.

Sitanggan, E. P. O. \& Purnomo, C. W. (2017) The Effects of Binder on the Release of Nutrient from Matrix-Based Slow Release Fertilizer. Materials Science Forum, 886, 138-144.
Trenkel, M. E. (1997) Controlled-release and stabilized fertilizers in agriculture. Paris: International Fertilizer Industry Association.

Trinh H. T., Shaari K. Z. K., Shuib A. S., and Ismail L. (2013) Modeling of urea release from coated urea for prediction of coating material diffusivity. Proceeding of the 6th International Conference on Process Systems Engieering. Kuala Lumpur, Malaysia (pp 20-30).

Xiang, Y. \& Ji-yun, J. (2008) Recent Advances on the Technologies to Increase Fertilizer Use Efficiency. Agriculture Science in China, 7(4), $469-479$. 